\title{
Pertumbuhan dan Sintasan Ikan Nila (Oreochromis niloticus) yang diberi Kombinasi Pakan Buatan Dari Tepung Cacing Tanah (Pheretima sp.) dan Alga Coklat (Sargassum spp.)
}

\author{
Hilyadi Edstiv Bagayo ${ }^{1}$, Junardi ${ }^{1}$, Tri Rima Setyawati ${ }^{1}$ \\ ${ }^{1}$ Program Studi Biologi, Fakultas MIPA, Universitas Tanjungpura, Jl. Prof. Dr. H. Hadari Nawawi, Pontianak, \\ Email: hilyadibagayo@gmail.com
}

\begin{abstract}
The potential for freshwater aquaculture in West Kalimantan is still high, including one of them is the Nile tilapia (Oreochromis niloticus). The purpose of this study was to determine the optimal growth and best survival rate by a combination of Fish, Earthworm Pheretima sp. and Brown seaweed Sargassum spp flour. The method used is Completely Randomized Design with four treatments and five replications. The result showed that treatments with $>60 \%$ plant raw materials shows the best resulting not only growth but also survival rate. Feed with a combination of these raw materials showed an allometric positive growth pattern.
\end{abstract}

Keywords: Feed Combination, Growth, Oreochromis niloticus, Pheretima sp, Sargassum spp

\section{PENDAHULUAN}

Perikanan air tawar di Indonesia, khususnya Kalimantan Barat memiliki potensi yang cukup besar untuk dikembangkan. Area perairan yang luas di Kalimantan Barat masih memungkinkan untuk dijadikan sebagai sentra produksi ikan air tawar. Salah satu ikan air tawar yang berpotensi untuk dibudidayakan di Kalimantan Barat adalah ikan nila (Oreochromis niloticus), karena memiliki nilai ekonomi tinggi, rasa yang enak dimakan dan mudah dibudidayakan.

Produksi ikan nila di Kalimantan Barat, khusus kolam budidaya pada tahun 2012 sebesar 38,92 ton, angka ini menunjukan bahwa hasil budidaya ikan nila masih rendah dibanding dengan produksi perikanan air tawar lain seperti ikan mas dengan jumlah produksi sebesar 44,46 ton pada tahun 2012 (Dislautkan KALBAR, 2012). Hasil produksi ikan tidak terlepas dari kebutuhan pakan dalam budidaya perikanan. Ketersediaan pakan memengaruhi hasil produksi perikanan, semakin banyak ikan yang dibudidayakan maka diperlukan juga pakan dalam jumlah yang besar. Ketersediaan pakan yang mencukupi secara berkelanjutan akan dapat meningkatkan hasil produksi perikanan.

Pakan dalam budidaya ikan dapat dibedakan menjadi pakan alami dan buatan. Pakan alami adalah pakan yang terdapat di lingkungan ikan hidup dan tidak dilakukan pengolahan pakan. Pakan buatan (pelet) merupakan makanan yang diramu dari beberapa macam bahan makanan yang nilai nutrisi dan daya cernanya sudah diatur kemudian diolah menjadi bentuk khusus (Mudjiman, 1995).
Kandungan nutrisi dalam pakan merupakan unsur yang penting dalam budidaya perikanan. Secara umum nutrisi yang harus terkandung di dalam pakan ikan diantaranya adalah protein, lemak, asam lemak esensial, karbohidrat, kalsium dan fosfor. Pakan komersial yang beredar di pasaran sudah diramu sehingga nutrisi yang terkandung sudah lengkap (Kordi, 2004). Pakan komersial yang terbuat dari tepung ikan tidak ekonomis untuk digunakan karena harganya yang mahal dan dapat mencapai 50-60\% dari keseluruhan biaya produksi (Asiah, 2014). Selain itu, suplai tepung ikan tidak stabil di pasaran dan penggunaan tepung ikan sebagai bahan pakan berakibat pada penurunan populasi ikan di alam sehinga perlu dicari alternatif bahan pengganti.

Bahan-bahan yang berpotensi untuk digunakan sebagai pengganti tepung ikan diantaranya adalah tepung cacing tanah (Pheretima sp.) dan tepung Sargassum spp. Potensi kedua jenis pakan Pheretima sp. dan Sargassum spp. sangat tinggi di Kalimantan Barat. Ketersediaan kedua jenis pakan ini juga masih banyak. Faktor penting tersebut memungkinkan terjaminnya suplai bahan baku pakan secara berkelanjutan untuk budidaya ikan nila

\section{BAHAN DAN METODE}

\section{Waktu dan Tempat Penelitian}

Penelitian ini dilaksanakan selama tiga bulan, yaitu dari bulan Oktober-Desember 2017. Penelitian dilakukan di Laboratorium Zoologi Jurusan Biologi dan Laboratorium Riset dan 
Pengembangan Jurusan Kimia FMIPA Universitas Tanjungpura.

\begin{abstract}
Alat dan Bahan
Peralatan dan bahan-bahan yang digunakan dalam penelitian ini adalah akuarium, aerator, timbangan digital idealife "IL-200p", micrometer digital "mitutoyo", serokan, selang penyipon, lampu LED, ember, thermometer $\mathrm{Hg}$, kertas $\mathrm{pH}$, test kit $\mathrm{NH}_{3}$, botol Winkler, Erlenmeyer, spuit, pipet tetes, $\mathrm{KOH}-\mathrm{KI}, \mathrm{MnSO}_{4}, \mathrm{H}_{2} \mathrm{SO}_{4}, \mathrm{Na}_{2} \mathrm{~S}_{2} \mathrm{O}_{3}$, indikator pp, amilum, ikan uji (Oreochromis niloticus) yang berusia 1bulan yang berasal dari Balai Benih Ikan (BBI) Kota Pontianak dengan panjang tubuh 3-5 cm dan bobot 2-4 gram, tepung cacing Pheretima sp., dedak halus, tepung ikan, tepung kanji "rose brand", tepung Sargassum spp., dan premik "super mix".
\end{abstract}

\section{Rancangan Penelitian}

Penelitian ini menggunakan rancangan acak lengkap (RAL) terdiri dari 4 perlakuan yakni Perlakuan A (kontrol), perlakuan B (Tepung ikan $10 \%$, tepung Pheretima sp $70 \%$, tepung Sargassum spp 20\%), perlakuan C (Tepung Ikan $10 \%$, tepung Pheretima sp 50\%, tepung Sargassum spp 40\%), perlakuan D (Tepung Ikan $10 \%$, tepung Pheretima sp 30\%, tepung Sargassum spp 60\%). Perlakuan masing-masing terdiri atas 5 terdiri dari 5 ulangan sehingga diperoleh 20 unit percobaan.

\section{Prosedur Kerja}

Persiapan Penelitian

Tahap awal penelitian adalah pembuatan pakan yang meliputi pengeringan cacing tanah (Pheretima sp.) dan Alga coklat (Sargassum spp.) setelah kering bahan-bahan tersebut kemudian ditumbuk dan diayak sehingga diperoleh tepung dari masing-masing bahan. Tepung tersebut kemudian dianalisis proksimat di Laboratorium Aneka Komoditi Balai Riset dan Standarisasi Industri (Baristand) untuk mengetahui kadar protein dari masing-masing bahan. Persiapan wadah Sterofoam ukuran 40x30x30 cm3 dengan diisi air sebanyak 24 liter sebelum benih ditebar (Centyana, 2014). Wadah yang digunakan sebanyak 20 wadah. Aerasi dilakukan selama 2 jam sebelum dilakukan penebaran benih ikan dan penggantian air sebanyak $50 \%$ dari total air sebelumnya. Penggantian air dilakukan seminggu sekali dan pembuangan kotoran ikan selama penelitian dilakukan dengan cara penyiponan.

Ikan uji sebelum ditebar dalam wadah penelitian, terlebih dahulu dilakukan aklimasi selama satu minggu sehingga ikan dapat beradaptasi dengan lingkungan baru. Selama proses aklimasi ikan diberi pakan buatan yang diramu sendiri yang sesuai dengan formulasi yang sudah ditentukan. Ikan uji semua dipuasakan selama satu hari sebelum dilakukan perlakuan.

\section{Pelaksanaan Penelitian}

Ikan uji ditimbang untuk mengetahui bobot awal pada penelitian serta untuk mengetahui dosis pakan yang diberikan. Ikan uji dimasukan ke dalam bak pemeliharaan dengan padat tebar 5 ekor/wadah dengan volume air dalam wadah sebanyak 12 liter. Pakan diberikan sebanyak dua kali sehari yaitu pada pukul 08.00 WIB dan 18.00 WIB. Pemberian pakan 5\% dari bobot tubuh total ikan (Djhariah, 1995). Setiap 10 hari sekali dilakukan pengamatan terhadap bobot, kematian ikan uji dan kualitas air (suhu, $\mathrm{DO}, \mathrm{pH}, \mathrm{NH}_{3}$ dan $\mathrm{CO}_{2}$ ).

\section{Variabel pengukuran}

Variabel yang diukur dalam penelitian ini adalah pertumbuhan yang diketahui melalui pertambambahan bobot dan panjang tubuh serta sintasan (survival rate). Data lain sebagai pendukung juga diukur seperti suhu, $\mathrm{pH}, \mathrm{DO}$, $\mathrm{CO}_{2}$ dan $\mathrm{NH}_{3}$ (Amoniak)

Pertambahan bobot dan panjang tubuh ikan dihitung dengan menggunakan rumus:

$$
\mathrm{G}=\mathrm{W}_{\mathrm{t}}-\mathrm{W}_{0}
$$

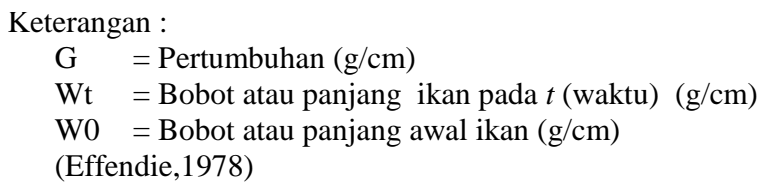

Data hubungan panjang dan bobot tubuh digunakan untuk melihat kesesuaian antara pertumbuhan panjang tubuh dengan bobot tubuh. Rumus yang digunakan adalah:

$$
\mathrm{W}=\mathrm{aL}^{\mathrm{b}}
$$

Data ditransformasikan ke dalam bentuk logaritma, sehingga menjadi

$$
\log W=\log a+b \log L
$$

Keterangan :

$$
\begin{aligned}
\mathrm{W} & =\text { Bobot }(\mathrm{g}) \\
\mathrm{L} & =\text { Panjang total }(\mathrm{cm}) \\
\mathrm{a} & =\text { Konstanta } \\
\mathrm{b} & =\text { Koefisien allometrik }
\end{aligned}
$$


Sintasan dinyatakan sebagai persentase jumlah ikan yang hidup selama jangka waktu pemeliharaan dibagi dengan jumlah ikan yang ditebar.

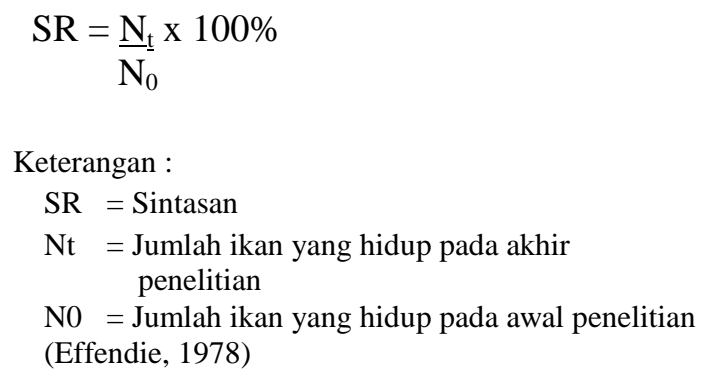

\section{Analisis Data}

Sebelum dianalisis, data hasil penelitian diuji normalitasnya. Data dengan distribusi normal kemudian dianalisis dengan Analisis Varian (Anava) dengan tingkat kepercayaan 95\%, sedangkan data yang tidak terdistribusi normal digunakan uji Kruskal Wallis.

\section{HASIL DAN PEMBAHASAN}

\section{Hasil}

Penambahan bobot tubuh ikan nila (Oreochromis niloticus) lebih besar terjadi pada ikan yang diberi pakan kombinasi tepung cacing (Pheretima sp.) dan alga coklat (Sargassum spp.) dibandingkan dengan ikan kontrol. Kombinasi pakan yang paling baik untuk meningkatkan bobot dan panjang tubuh ikan nila adalah pakan dengan kombinasi $10 \%$ tepung ikan, 30\% tepung cacing dan 60\% tepung Sargassum spp. (Tabel 1 dan 2).

Hasil analisis variansi (Anova) menunjukan bahwa pemberian kombinasi pakan tepung cacing tanah Pheretima sp. dan alga coklat Sargassum spp. pada ikan nila (Oreochromis niloticus) dengan kelompok perlakuan A, C dan D tidak berbeda nyata terhadap rerata pertumbuhan bobot dan panjang tubuh ikan, namun berbeda nyata dengan perlakuan B. Rerata nilai paling tinggi terdapat pada perlakuan D yaitu bobot tubuh sebesar 5.18 gr dan panjang tubuh sebesar 6.88 cm (Tabel 3).

Peningkatan bobot ikan nila (Oreochromis niloticus) yang diberi kombinasi pakan tepung cacing (Pheretima sp.) dan alga coklat (Sargassum spp.) menunjukkan bahwa pakan D memberikan pengaruh paling tinggi di setiap sepuluh hari pemeliharaan dibanding pakan lainnya. Pertumbuhan ikan nila yang diberi pakan
A mempunyai pertumbuhan paling signifikan pada hari ke-50 sampai hari ke-60 masa pemeliharaan (Gambar 1).

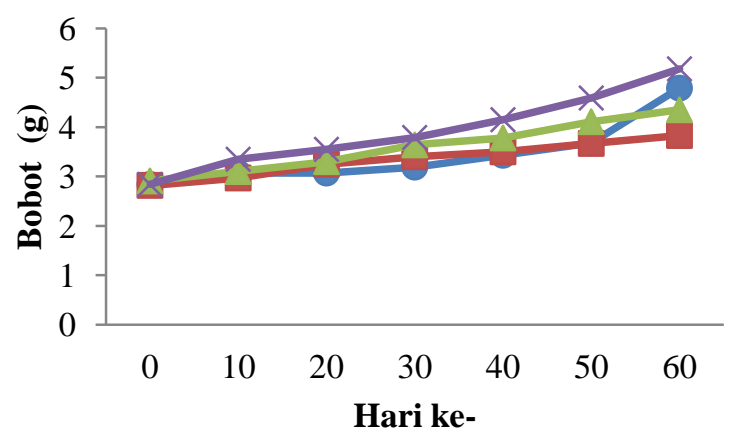

Gambar 1. Kurva pertambahan bobot ikan nila (Oreocromis niloticus) yang diberi kombinasi pakan tepung cacing Pheretima sp. dan Sargassum spp. selama penelitian. Keterangan: • (Perlakuan A), - (Perlakuan B), A (Perlakuan C), x (Perlakuan D).

Pertumbuhan panjang tubuh ikan nila (Oreochromis niloticus) yang diberi pakan D memiliki pertambahan panjang paling besar pada setiap sepuluh hari pengamatan. Pertambahan panjang tubuh ikan nila yang signifikan terjadi pada Pakan B hari ke-10 sampai hari ke-20, selanjutnya Pakan A pada hari ke-50 sampai hari ke-60 masa pemeliharaan (Gambar 2).

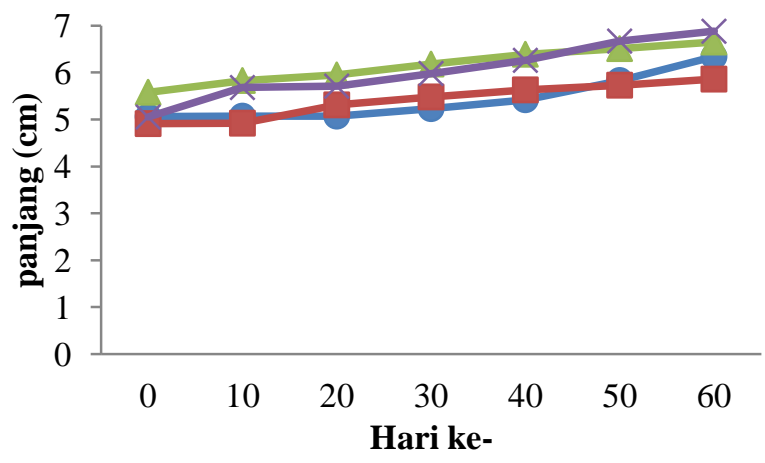

Gambar 2. Kurva penambahan panjang tubuh ikan nila (Oreocromis niloticus) yang diberi kombinasi pakan tepung cacing Pheretima sp. dan Sargassum spp. selama penelitian. Keterangan: • (Perlakuan A), - (Perlakuan B), $\triangle$ (Perlakuan C), x (Perlakuan D)

Hasil analisis hubungan panjang tubuh dan bobot tubuh ikan pada penelitian ini didapatkan nilai $b$ $=3,87$, dan masuk kategori alometrik positif (Gambar 3). 


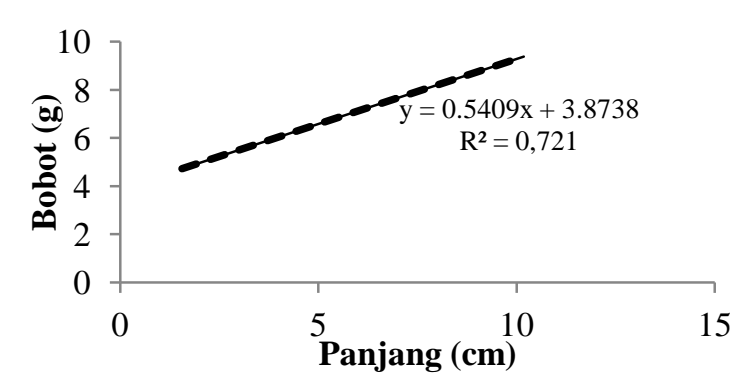

Gambar 3. Hubungan panjang tubuh dan bobot ikan nila (Oreocromis niloticus) yang diberi kombinasi pakan tepung cacing Pheretima sp. dan Sargassum spp selama penelitian.
Selain penambahan bobot tubuh dan panjang tubuh ikan kombinasi pakan tepung cacing (Pheretima sp.) dan alga coklat (Sargassum spp.) juga berpengaruh pada sintasan ikan nila (Oreochromis niloticus). Kombinasi 10\% tepung ikan, 30\% tepung cacing dan 60\% tepung Sargassum spp (Pakan D) mampu meningkatkan harapan hidup ikan sebanyak 80\% (Tabel 4).

Hasil analisis proksimat pakan yang digunakan pada penelitian ini menunjukan bahwa pakan $\mathrm{A}$ mengandung protein paling besar dibanding pakan yang lain. Selanjutnya kandungan proksimat lain seperti kadar air yang paling besar terdapat pada pakan B, kadar lemak terbesar pada pakan $\mathrm{C}$ dan kadar karbohidrat dan abu paling besar terdapat pada pakan D (Tabel 5).

Tabel 1. Bobot tubuh ikan nila (Oreocromis niloticus) (g) yang diberi kombinasi pakan tepung cacing Pheretima sp. dan alga coklat Sargassum spp.

\begin{tabular}{|c|c|c|c|c|c|c|c|}
\hline \multirow{2}{*}{ Perlakuan } & \multicolumn{7}{|c|}{ Hari ke- } \\
\hline & 0 & 10 & 20 & 30 & 40 & 50 & 60 \\
\hline A (Kontrol) & $2,84 \pm 0,86$ & $3,07 \pm 0,95$ & $3,07 \pm 1,07$ & $3,19 \pm 0,99$ & $3,43 \pm 1,47$ & $3,68 \pm 1,32$ & $4,79 \pm 1,6$ \\
\hline B & $2,82 \pm 0,70$ & $2,97 \pm 0,83$ & $3,25 \pm 1,00$ & $3,40 \pm 1,07$ & $3,50 \pm 1,16$ & $3,67 \pm 1,42$ & $3,83 \pm 1,53^{*}$ \\
\hline $\mathrm{C}$ & $2,91 \pm 0,72$ & $3,10 \pm 0,70$ & $3,30 \pm 0,78$ & $3,64 \pm 0,78$ & $3,78 \pm 1,15$ & $4,11 \pm 1,20$ & $4,35 \pm 1,22$ \\
\hline D & $2,84 \pm 0,98$ & $3,35 \pm 1,17$ & $3,55 \pm 1,31$ & $3,79 \pm 1,44$ & $4,15 \pm 1,59$ & $4,59 \pm 1,80$ & $5,18 \pm 2,01^{* *}$ \\
\hline
\end{tabular}

Keterangan: * nilai paling kecil antar perlakuan, ** nilai paling besar antar perlakuan, Perlakuan A (kontrol), perlakuan B (T. Ikan 10\%, T. Pheretima sp 70\%, T. Sargassum spp 20\%), Perlakuan C (T. Ikan 10\%, T. Pheretima sp 50\%, T. Sargassum spp 40\%), Perlakuan D (T. Ikan 10\%, T. Pheretima sp 30\%, T. Sargassum spp 60\%)

Tabel 2. Pertambahan panjang $(\mathrm{cm})$ tubuh ikan nila (Oreocromis niloticus) yang diberi kombinasi pakan tepung cacing tanah Pheretima sp. dan alga coklat Sargassum spp.

\begin{tabular}{cccccccc}
\hline \multirow{2}{*}{ Perlakuan } & \multicolumn{7}{c}{ Hari ke- } \\
\cline { 2 - 8 } & 0 & 10 & 20 & 30 & 40 & 50 & 60 \\
\hline A (Kontrol) & $5,06 \pm 0,81$ & $5,07 \pm 0,76$ & $5,07 \pm 0,66$ & $5,23 \pm 0,67$ & $5,42 \pm 1,70$ & $5,83 \pm 0,63$ & $6,34 \pm 0,61$ \\
B & $4,91 \pm 0,87$ & $4,92 \pm 0,97$ & $5,31 \pm 1,02$ & $5,48 \pm 1,06$ & $5,63 \pm 1,04$ & $5,73 \pm 1,30$ & $5,86 \pm 1,32^{*}$ \\
C & $5,58 \pm 0,51$ & $5,83 \pm 0,43$ & $5,95 \pm 0,49$ & $6,18 \pm 0,43$ & $6,39 \pm 0,73$ & $6,51 \pm 0,78$ & $6,65 \pm 0,81$ \\
D & $5,05 \pm 0,62$ & $5,68 \pm 0,57$ & $5,71 \pm 0,59$ & $5,98 \pm 0,60$ & $6,26 \pm 0,81$ & $6,67 \pm 0,92$ & $6,88 \pm 0,85^{* *}$ \\
\hline
\end{tabular}

Keterangan: * nilai paling kecil antar perlakuan, ** nilai paling besar antar perlakuan, Perlakuan A (kontrol), perlakuan B (T. Ikan 10\%, T. Pheretima sp 70\%, T. Sargassum spp 20\%), Perlakuan C (T. Ikan 10\%, T. Pheretima sp 50\%, T. Sargassum spp 40\%), Perlakuan D (T. Ikan 10\%, T. Pheretima sp 30\%, T. Sargassum spp 60\%)

Tabel 3. Hasil uji statistik bobot dan panjang tubuh ikan nila (Oreocromis niloticus) yang diberi kombinasi pakan tepung cacing Pheretima sp. dan Sargassum spp.

\begin{tabular}{ccccc}
\hline Variabel pengukuran & \multicolumn{4}{c}{ Perlakuan } \\
\cline { 2 - 5 } & $\mathrm{A}$ & $\mathrm{B}$ & $\mathrm{C}$ & $\mathrm{D}$ \\
\hline Bobot $(\mathrm{g})$ & $4,79 \pm 1,20^{\mathrm{a}}$ & $3,83 \pm 1,42^{\mathrm{b}}$ & $4,35 \pm 1,04^{\mathrm{ac}}$ & $5,18 \pm 1,51^{\mathrm{acd}}$ \\
Panjang $(\mathrm{cm})$ & $6,33 \pm 0,36^{\mathrm{a}}$ & $5,85 \pm 0,91^{\mathrm{b}}$ & $6,65 \pm 0,48^{\mathrm{ac}}$ & $6,88 \pm 0,50^{\text {abcd }}$ \\
\hline
\end{tabular}

Keterangan: Simbol yang berbeda pada kolom yang sama menunjukan perbedaan nyata $(\mathrm{p}<0,05)$, Perlakuan A (kontrol), perlakuan B (T. Ikan 10\%, T. Pheretima sp 70\%, T. Sargassum spp 20\%), Perlakuan C (T. Ikan 10\%, T. Pheretima sp 50\%, T. Sargassum spp 40\%), Perlakuan D (T. Ikan 10\%, T. Pheretima sp 30\%, T. Sargassum spp 60\%) 
Tabel 4. Sintasan ikan nila (Oreocromis niloticus) yang diberi kombinasi pakan tepung cacing Pheretima sp. dan Sargassum spp. selama penelitian

\begin{tabular}{ccccc}
\hline \multirow{2}{*}{ Variabel pengukuran } & $\mathrm{A}$ & $\mathrm{B}$ & $\mathrm{C}$ & $\mathrm{D}$ \\
\cline { 2 - 5 } & 64 & $56^{*}$ & 68 & $80^{* *}$ \\
\hline Sintasan (\%) & 64 . & \\
\hline Keterangan: * nilai paling kecil antar perlakuan, ** nilai paling besar antar perlakuan, Perlakuan A (kontrol), \\
perlakuan B (T. Ikan 10\%, T. Pheretima sp 70\%, T. Sargassum spp 20\%), Perlakuan C (T. Ikan 10\%, T. \\
Pheretima sp 50\%, T. Sargassum spp 40\%), Perlakuan D (T. Ikan 10\%, T. Pheretima sp 30\%, T. Sargassum \\
spp 60\%)
\end{tabular}

Tabel 5. Hasil analisis kandungan nutrisi dalam pakan buatan dengan kombinasi bahan tepung cacing Pheretima sp. dan Sargassum spp.

\begin{tabular}{lcccc}
\hline \multirow{2}{*}{ Variabel (\%) } & \multicolumn{4}{c}{ Pakan } \\
\cline { 2 - 5 } & $\mathrm{A}$ & $\mathrm{B}$ & $\mathrm{C}$ & $\mathrm{D}$ \\
\hline Kadar Air & 12,67 & 22,87 & 10,35 & 17,01 \\
Kadar Abu & 6,53 & 10,35 & 14,26 & 16,40 \\
Protein & 31,14 & 30,33 & 23,66 & 20,08 \\
Lemak & 12,80 & 20,26 & 20,82 & 15,64 \\
Karbohidrat & 15,07 & 22,45 & 20,12 & 22,48 \\
\hline
\end{tabular}

Keterangan: Perlakuan A (kontrol), perlakuan B (T. Ikan 10\%, T. Pheretima sp 70\%, T. Sargassum spp 20\%), Perlakuan C (T. Ikan 10\%, T. Pheretima sp 50\%, T. Sargassum spp 40\%), Perlakuan D (T. Ikan 10\%, T. Pheretima sp 30\%, T. Sargassum spp 60\%)

\section{Pembahasan}

Perlakuan yang memiliki pengaruh paling baik dalam meningkatkan pertambahan bobot dan panjang ikan nila (O. niloticus) dalam penelitian ini adalah perlakuan D (60\% tepung Sargassum spp.: 30\% tepung Pheretima sp.: 10\% tepung ikan), sedangkan pakan yang memiliki pengaruh paling rendah adalah perlakuan B (20\% tepung Sargassum spp.: $70 \%$ tepung Pheretima sp.: $10 \%$ tepung ikan) (Tabel 1). Hal ini disebabkan karena ikan nila lebih suka mengkonsumsi pakan D yang mengandung Sargassum spp. lebih banyak dibandingkan pakan lain. Satria et al. (2011) menyatakan bahwa ikan nila merupakan jenis ikan omnivora atau pemakan segala, namun cenderung herbivora atau lebih banyak mengkonsumsi mengkonsumsi pakan berbahan dasar tumbuhan seperti kelompok Cholorophyceace, Myxophyceace, dan Desmid. Menurut Asha et al., (2004) Sargassum spp. mengandung senyawa growth promoter untuk pertumbuhan ikan yaitu dengan meningkatkan efisiensi penyerapan nutrisi dari pakan.

Hasil uji analisis variansi (Anova) (Tabel 3) untuk bobot ikan menunjukan bahwa kelompok perlakuan pakan $\mathrm{A}, \mathrm{C}$ dan $\mathrm{D}$ tidak berbeda nyata terhadap penambahan bobot tubuh namun berbeda nyata dengan perlakuan B. Pakan buatan yang menghasilkan penambahan bobot tertinggi adalah pakan D yaitu sebesar $82,53 \%$ dan yang terendah terjadi pada pakan B yaitu sebesar
35,96\%. Hal ini disebabkan oleh tingkat kesukaan dan kadar protein dalam pakan yang diberikan pada ikan.

Pakan D dapat meningkatkan pertumbuhan ikan, selain karena disukai ikan dan kandungan serat yang tinggi, pakan $\mathrm{D}$ juga mengandung imunostimulan (polisakarida alginat dan sodium alginat) yang terdapat pada Sargassum spp. Kedua bahan tersebut dapat digunakan sebagai feed supplement (Sahara et al., 2015). Menurut Sahara et al., (2015) Kandungan feed suplement dalam pakan berfungsi sebagai pelengkap dan pemenuhan kebutuhan mikro nutrisi yang penting dalam merangsang pertumbuhan ikan. Menurut Handayani (2004), mikro nutrisi yang terkandung dalam Sargassum spp. antara lain vitamin A, C dan zat-zat mineral seperti abu, kalsium, besi, dan fosfor.

Hasil uji analisis variansi (Anova) untuk panjang tubuh ikan nila menunjukan bahwa perlakuan pakan A, B, C dan D tidak berbeda nyata terhadap penambahan panjang tubuh ikan nila. Pertumbuhan terendah terdapat pada kelompok perlakuan B yaitu dengan persentase pertumbuhan sebesar $19,10 \%$. Selanjutnya, penambahan panjang paling baik ditemukan pada perlakuan D dengan presentase sebesar 36,19\%. Hal ini disebabkan oleh adanya kandungan 
kalsium dan fosfat yang tinggi pada perlakuan D yang berasal dari Sargassum spp.

Rumput laut Sargassum spp. mengandung kalsium sebesar 1540,66 mg/100g, sedangkan fosfor sebesar 474,03 gram/100g (Handayani et al., 2004). Kandungan kalsium (Ca) dan fosfor (P) dalam pakan saling bersinergis, kandungan kedua mikro nutrisi ini dalam pakan harus seimbang untuk mendapatkan pertumbuhan tulang ikan yang optimal. Kalsium dalam pakan akan membantu pertumbuhan tulang, kulit, serta sisik ikan, sedangkan fosfor digunakan untuk proses mineralisasi tulang. Penelitian yang dilakukan oleh Zainuddin (2010) menunjukan ada peningkatan kadar abu pada tulang ikan kerapu macan (Epinephelus fuscoguttatus) yang diberi penambahan kalsium dan fosfor pada pakan sebesar $18 \mathrm{~g}$ kalsium dan $6 \mathrm{~g}$ fosfor per kilogram. Hal tersebut menunjukan bahwa penambahan kalsium pada pakan berpengaruh pada pertumbuhan tulang ikan kerapu macan.

Selain kandungan kalsium dan fosfor pada Sargassum spp. sebagai faktor utama, besarnya kandungan protein pada cacing tanah (Pheretima sp.) juga membantu meningkatkan pertumbuhan panjang ikan nila. Berdasarkan uji proksimat yang telah dilakukan pada tepung cacing tanah (Pheretima sp.) mengandung protein sebesar 31,2 $\%$.

Penambahan bobot dan panjang ikan tertinggi terdapat pada perlakuan $\mathrm{D}$ dan yang terendah terdapat pada perlakuan B (Tabel 1 dan 2). Analisis hubungan bobot-panjang (Gambar 3) menunjukan bahwa bentuk hubungan pertumbuhan tubuh ikan nila adalah allometrik positif. Menurut Jabarsyah et al., (2009) hubungan panjang dan bobot dapat dilihat dari konstanta $b$, yaitu bila nilai $b=3$, hubungan yang terbentuk adalah isometrik. Bila nilai $b>3$, maka hubungan yang terbentuk adalah allometrik positif dan jika nilai $b<3$ maka hubungan yang terbentuk adalah allometrik negatif. Ikan nila pada penelitian ini memiliki hubungan allometrik positif hal ini terjadi karena ikan nila cenderung lebih banyak diam akibat keterbatasan ruang dalam wadah peneliharaan sehingga terjadi penumpukan nutrisi karena tidak dikonversi menjadi energi sehingga menyebabkan bobot tubuh ikan terus meningkat. Hasil penelitian ini berbeda dengan hasil penelitian yang didapatkan oleh Salmadinah et al., (2017) yang mendapatkan hubungan bobot-panjang tubuh isometrik pada ikan nila yang hidup di rawa, dengan demikian ruang menjadi faktor penting yang memengaruhi pertumbuhan ikan nila.

Sintasan ikan nila selama penelitian terendah pada perlakuan B sebesar 56\% dan tertinggi pada perlakuan D dengan nilai mencapai $80 \%$. Sintasan pada perlakuan B yang rendah disebabkan oleh laju konsumsi pakan lebih rendah. Pakan B merupakan pakan yang paling rendah dikonsumsi oleh ikan nila, hal ini disebabkan oleh tingginya kandungan air dalam pakan B sebesar 22,87\% (Tabel 5). Faktor ini diduga menyebabkan pakan mudah tenggelam dan terlarut dalam air sehingga tidak memungkinan ikan untuk mengkonsumsi pakan yang lebih banyak. Sedikitnya pakan yang dikonsumsi oleh ikan akan menyebabkan terjadinya defisiensi nutrisi yang berakibat pada kurangnya nutrisi yang terserap oleh tubuh ikan dan secara tidak langsung akan menyebabkan ikan mudah stress dan mudah terserang penyakit (Astikasari, 2011).

Sintasan ikan yang paling tinggi ditemukan pada pakan D. Hal ini disebabkan oleh laju konsumsi pakan dan kandungan Sargassum spp. yang tinggi pada pakan. Kandungan keragenan yang ada pada Sargassum spp. menyebabkan pakan ini tidak mudah terlarut dalam air dan tidak mudah tengelam sehingga peluang pakan untuk dikonsumsi lebih tinggi. Selain itu, Sargassum spp. juga mengandung imunostimulan yang dapat meningkatkan sistem imun dan resistensi ikan terhadap patogen. Kandungan imunostimulan dalam pakan ini akan meningkatkan jumlah total hemosit yang berperan pada ketahanan tubuh ikan (Sahara et al., 2015). Hal ini juga didukung oleh penelitian yang dilakukan oleh Huxley dan Lipton (2009), yang diujikan pada udang putih ( $L$. vanamei) yang menunjukan adanya peningkatan jumlah hemosit yang berfungsi pada imunitas dan resistensi bakteri patogen pada tubuh udang putih (L. vanamei).

Kombinasi tepung Pheretima sp. dan tepung Sargassum spp. memberikan pengaruh nyata pada penambahan bobot sebesar 5,18 $\mathrm{g}$ dan panjang tubuh sebesar $6,88 \mathrm{~cm}$ Kombinasi tepung Pheretima sp. (30\%), Sargassum spp. (60\%) dan tepung ikan (10\%) merupakan komposisi pakan yang memberikan pengaruh paling baik untuk pertumbuhan ikan nila dengan nilai sintasan ikan mencapai $80 \%$. 


\section{DAFTAR PUSTAKA}

Asha, P,S, Rajagopalan, V \& Dikawar, K, 2004, Effect of Seaweed, Seagrass and Powdered Algae in Rearing the Hatchery Produced Juveniles of Holothuria (Metriatyla) Scabra, Central Marine Ficheries Research Institute, Kochi, Kerala

Asiah, N S, Indra, \& Siska, W, 2015, Substitusi Tepung Cacing Tanah dalam Pakan untuk Pertumbuhan dan Efisiensi Pakan Ikan Baung (Mystus nemurus cv), Skripsi, Universitas Riau, Riau

Asmawi, S, 1983, Pemeliharaan Ikan Dalam Keramba, Gramedia, Jakarta

Astikasari, Tri Rima, S, dan Padmarsari F X D, 2011, Substitusi Ampas Tahu dalam Pakan Buatan terhadap Pertumbuhan Ikan Jelawat (Leptobarbus hoevenii), Skripsi, Universitas Tanjungpura, Pontianak

Centyana, E, Cahyoko, Y, \& Agustono, 2014, 'Substitusi Tepung Kedelai dengan Tepung Biji Koro Pedang (Canavalia ensiformis) terhadap Pertumbuhan, Survival Rate, dan Efisiensi Pakan Ikan Nila Merah' Jurnal Ilmiah Perikanan dan Kelautan vol. 6, no. 1, < http://repository.unair.ac.id/>

Djarijah, A S, 1995, Pakan Ikan Alami, Penerbit Kanisius, Yogyakarta

Dinas Kelautan dan Perikanan Provinsi Kalimantan Barat, 2011, Statistik Perikanan Tangkap, Perikanan Budidaya, Ekspor - Impor Setiap Kabupaten / Kota di Kalimantan Barat , Pontianak (Laporan tahunan) diaskes tanggal 17 Desember 2018, < http://kalbarprov.go.id/>

Effendie, M I, 1978, Biologi Perikanan, Studi Natural Histories Bagian I, Fakultas Perikanan IPB, Bogor

Huxley, A, D, J \& Lipton A, P, 2009, 'Immunodulatory Effect of Sargassum sp. on Peneaus monodon (Fab.)' The Asian Journal of Animal Science vol. 4, no. 2, hal.192-196, <http://researchjournal.co.in>

Handayani, Tri, 2004, 'Analisis Komposisi Rumput Laut Sargassum rassifolium J. Agardh’ Jurnal
Biofarmasi, vol. 2, no. 2, hal.45-52, < http://biosains.mipa.uns.ac.id>

Jabarsah, A, Firdaus, M, dan Nursidik, 2009, 'Faktor Kondisi Ikan Tenggiri Batang (Scomberomorus lineatus), Bawal Putih (Pampus argentus) dan Ikan Senangin (Eleutheronema tetradactylum) yang tertangkap dengan gillnet diperairan pantai amal tarakan' Jurnal ilmu perikanan diaskes 12 November 2018, < http://oseangrafi.lipi.go.id>

Mudjiman, A, 1995, Makan Ikan, Penerbit PT. Penebar. Swadaya, hlm 14-17, 49-51 Jakarta

Kordi, K \& Tancung, A B, 2004, Pengelolaan Kualitas Air dalam Budidaya Perairan, PT. Rhineka Cipta, Jakarta

Sahara, R, Anugrah \& Karoza A S, 2015, 'Evaluasi Tepung Alga Coklat (Sargassum cristaefolium) dalam Pakan terhadap Kinerja Pertumbuhan dan Efisiensi Pemanfaatan Pakan Benih Lele Dumbo (Clarias gariepinus)' Journal of Aquaculture management and Technology, vol. 4, no. 2, hal. 1-8, < http://ejournals1.undip.ac.id /index.php/jamt>

Salmadinah, S, Yasidi, F \& Kamri, S, 2017, 'Pola Pertumbuhan dan Kondisi Ikan Nila (Oreochromis niloticus) diperairan Rawa Aopa Watumohai Desa Pewutaa Kecamatan Angata Kabupaten Konawe Selatan' Jurnal Manajemen Sumber Daya Perairan vol. 2, no. 4, hal. 269275,

http://ojs.uho.ac.id/index.php/JMSP/article/vie wFile/3344/2517>

Satria, Y, Pelita, O, \& Yulfiperius, 2011, 'Kebiasaan Makan Ikan Nila (Oreochromis niloticus) di Danau Bekas Galian Pasir Gekbrong Cianjur Jawa Barat' Jurnal Agroqua, vol. 9, no. 1, < https://agroqua.unihaz.ac.id/index.php/>

Suryanto, S R, 2009, Nila, Penebar Swadaya, Yogyakarta

Zainuddin, 2010, Pengaruh Calcium dan Fosfor Terhadap Pertumbuhan, Efisiensi Pakan, Kandungan Mineral dan Komposisi Tubuh Juvenil Ikan Kerapu macan (Epinephelus fuscogulattus), Jurnal Ilmu dan Teknologi Kelautan Tropis Vol. 2 No. 2, Hal 1-9 